J. Perinat. Med. 8 (1980) 241

\section{Preliminary studies for a possible use of Doppler signals in the analysis of systolic time intervals of fetal heart}

\author{
Roversi, G. D., V. Canussio, M. Gargiulo*, E. Ferrazzi*, U. Nicolini*, B. Colla**, \\ 0. Visioli**, J. L. Beaussart***, E. Pedretti*, M. Saviotti**** \\ * $1^{0}$ Institute of Obstetric and Gynecology, University of Milan \\ ** Institute of Cardiovascular Diseases, University of Parma \\ *** Electronics Engeneer \\ **** Department of Cardiology, S. Carlo Hospital, Milan
}

\section{Introduction}

For more than ten years the foetal heart has been acoustically detectable with an ultrasound probe (DOPPLER effect) [1].

The DOPPLER signals of the foetal heart, transformed into electrical impulses, can be directely transmitted to a normal ink-writing system; this results in groups of irregular biphasic waves of high frequency. These signals are not always easily distinguished from one another [10].

By rectification (from biphasic to monophasic) and integration, we have transformed these waves into more simplified signals with a more regular shape [10]; the same process is used in the common cardiotocographs for the preliminary elaboration of the ultrasound (U.S.) signal of the foetal heart.

Our work and similar researches carried out on the U.S. signal of the foetal, adult and canine heart $[9,11,12,13]$ have shown that every cardiac cycle produces more than one signal.

This has created some difficultes in setting up foetal cardiotacometry but was seen as a possible, valuable source of information for foetal cardiac activity. In fact, the temporal relationship between the ECG and these U.S. waves suggested that they were the result of specific and different cardiac events $[3,11,12]$.
Many studies were carried out on the origin of cardiac U.S. signals. However only some of these were attributed to a specific event; in most of these researches these U.S. signals were studied using frequency filters, this being a different technique from ours $[3,9]$.

The aim of our present work was not to study the dynamic phenomena of the cardiac cycle which produces DOPPLER signals but to investigate the phases of the cardiac cycle during which these signals are produced.

If each signal can be related to a specific cardiac event one can then postulate more sophisticated usages of the Doppler fetal heart recording: the analysis of systolic time intervals.

\section{Material and methods}

In previous studies each foetal and adult cardiac cycle were seen to produce five DOPPLER signals $[3,12]$. The different phase of the cardiac cycle in which they appear could be identified with the simultaneous recording of parameters commonly used in cardiology (Fig. 1).

These parameters cannot be recorded from the foetus; therefore this preliminary study was carried out in the adult.

() by Walter de Gruyter \& Co. · Berlin - New York 


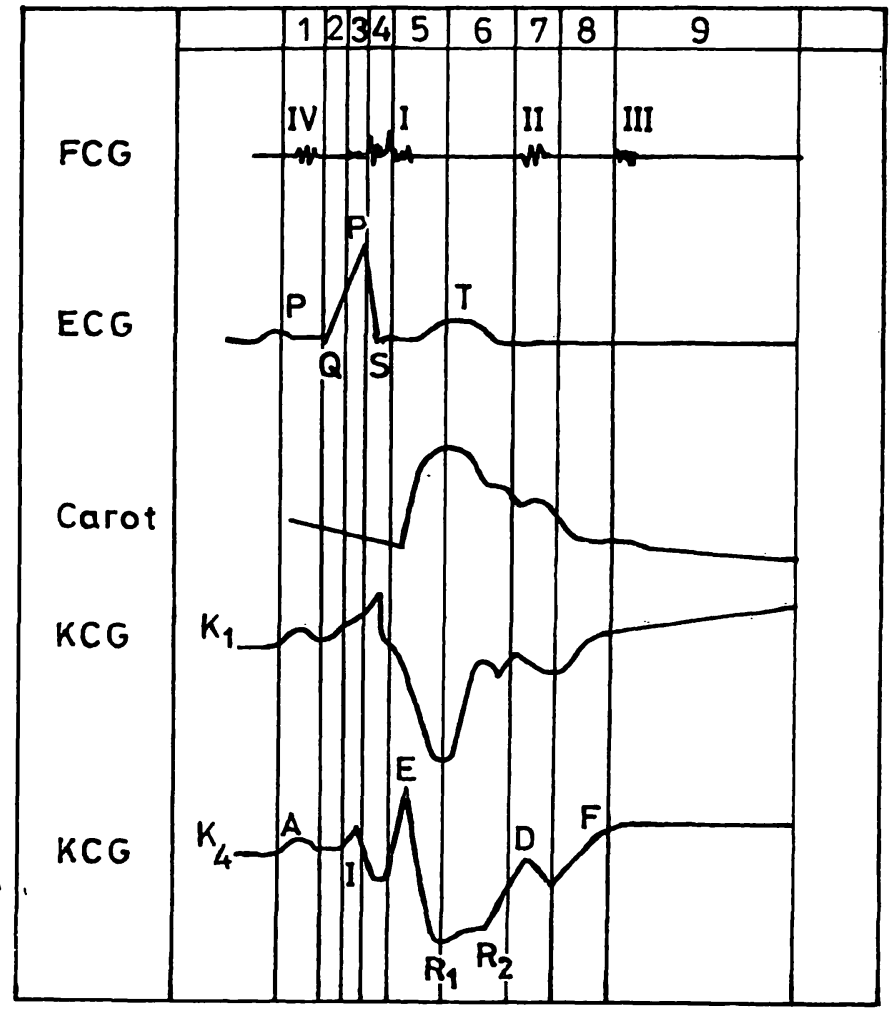

FCG $=$ Phonocardiogram

$E C G=$ Electrocardiogram

Carot. $=$ Carotid Pulse

KCG $=$ Kinetocardiogram

Fig. 1. Reference traces used in our study to identify the electromechanical phases. 1) atrial contraction. 2, 3) electromechanical latent phase. 4) isovolumetric contraction. 5) rapid ventricular ejection. 6) reduced ejection. 7) isovolumetric relaxation. 8) rapid filling. 9) reduced filling.

The following were recorded: the electrocardiogram (E. C. G.), the phonocardiogram (P. C. G.), the carotid arterial pulse (C. A.P.), and the kinetocardiogram (K. C. G.). The kinetocardiogram was obtained according to the methods described by E. E. Eddleman [2]. Precordial areas were $K_{1}$ and $\mathrm{K}_{4}$ (corresponding to E. C. G. in $\mathrm{V}_{1}$ and $\mathrm{V}_{4}$ ). These four recordings enabled us to obtain a precise timing of the electromechanical phases.

The Doppler signal was added to these traces. A $2.25 \mathrm{MHz}$ probe with a power of $28 \mathrm{~mW} / \mathrm{cm}^{2}$ was used.

The DOPPLER signal was rectified and integrated, as we have already described [12], by means of a BECKMAN coupleur $\mathrm{n}^{0} 9852$.

We defined the cardiac area with a teleroentgenogram before scanning it with the ultrasound transducer. Since the total cardiac area cannot be
Tab. I. Series of recordings.

\begin{tabular}{lll}
\hline Series of recordings & & \\
I & II & III \\
\hline US & US & US \\
P & P & P \\
CP & $\mathrm{K}_{1}$ & $\mathrm{~K}_{4}$ \\
ECG & ECG & ECG
\end{tabular}

US = ultrasound; $\quad \mathbf{P}=$ phonocardiogram; $\quad \mathbf{C P}=$ carotid pulse; $\quad \mathrm{K}_{1}=$ kinetocardiogram in $\mathrm{K}_{1} ; \mathrm{K}_{4}=$ kinetocardiogram in $\mathrm{K}_{\mathbf{4}} ; \mathbf{E C G}=$ electrocardiogram

scanned within the ultrasound beam - as it is easily accomplished studying fetal heart - the transducer was positioned in different points, to obtain a complete scanning.

Ultrasound signals and reference traces were recorded on a Dynograph BECKMAN RM Poligraph and registered on a four channels type recorder (H. P. 3960). Since we monitored six cardiac parameters and only had four channels we had to perform three sets of recordings (Tab. I).

Three cases were studied. These were healthy male subjects 27,29 and 35 years old. Objective and functional cardiac examinations were normal in all three cases. The traces of the three patients were very similar and hence statistical analy sis was limited to one case.

The number of cardiac cycles studied in this case was approximately 3000 .

\subsection{Statistical analysis}

This was carried out using a HewLETT-PACKARD 2100 computer. The digital-analogic conversion was executed at 500 points/sec channel.

The scheme of analysis adopted was the following:

\subsubsection{Definition of the time intervals during which the ultrasonic signals appear}

712 electrocardiographic complexes were analysed (338 in the first series, 259 in the second and 115 in the third). The $R-R$ time intervals were subdivided into 50 fractions, each lasting 20/1000 of R-R. Then a frequency polygon was constructed 


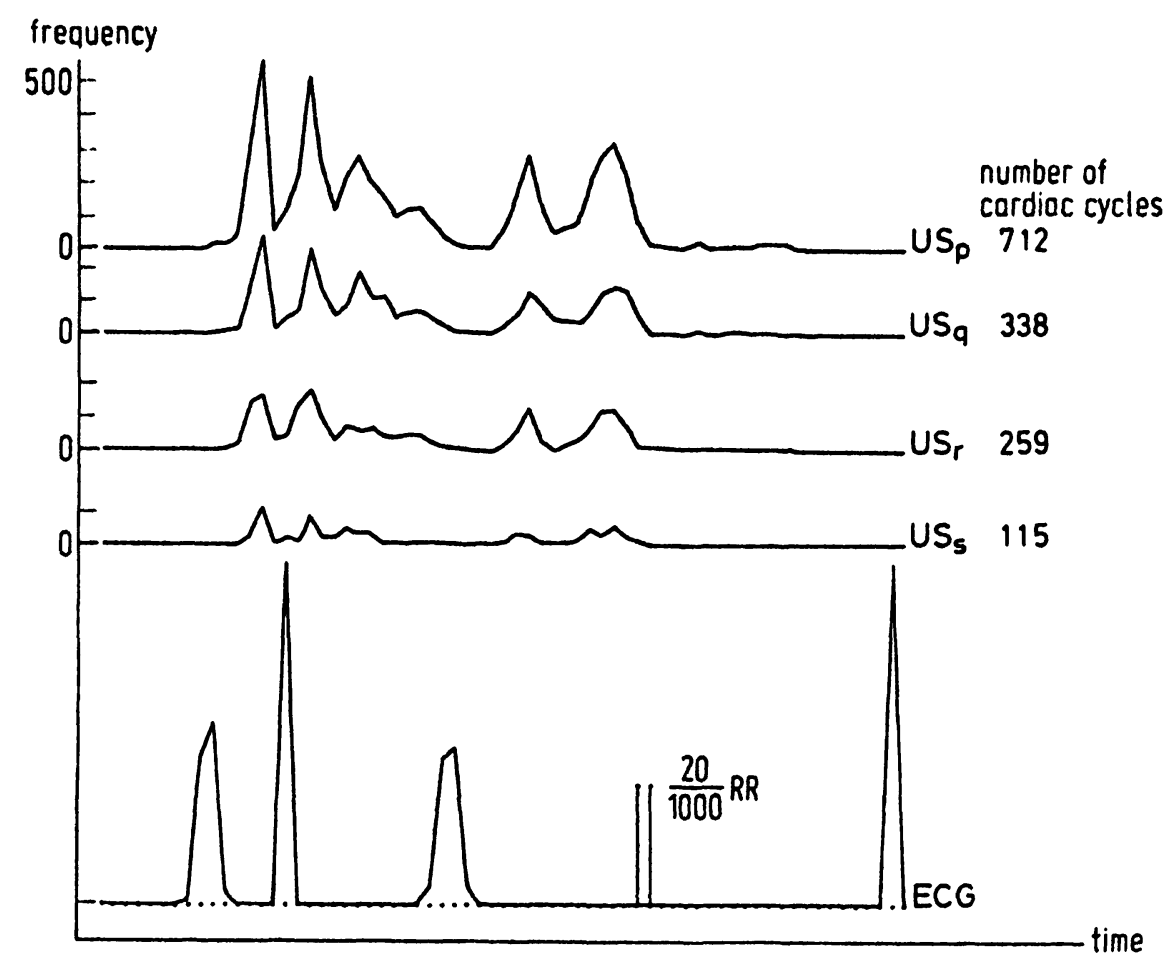

Fig. 2. Frequency of U. S. waves recorded (on ordinate):
a) in the first series (see Tab. I) of recording, U. S. q;
b) in the second series, U. S. r;
c) in the third series U. S., s;
d) in all series, U. S. p. Frequency are referred to each fraction of the R-R interval (abscissa).

(Fig. 2) putting R-R fractions on the abscissa the number of ultrasonic signals (appeared in each $R-R$ fraction) on the ordinate.

This polygon enabled us to determine six time intervals during which the ultrasonic signals appear with the highest frequency: each time interval was assigned a letter of the alphabet (Tab. II).

Tab. II. Time intervals during which the ultrasonic signals appear.

\begin{tabular}{llrr}
\hline $\begin{array}{l}\text { Time } \\
\text { interval }\end{array}$ & \multicolumn{3}{l}{ Position in the R-R interval } \\
& Rough & Thousandth of R-R \\
& & From & To \\
\hline A & P-R interval & -90 & 0 \\
B & QRS end & 15 & 90 \\
C & ST-T interval & 90 & 180 \\
D & Wave T & 180 & 270 \\
E & end T wave & 345 & 445 \\
F & T-P interval & 465 & 640 \\
\hline
\end{tabular}

\subsubsection{Determination of the electromechanical phases of cardiac activity during which ultrasonic signals appear}

The recorded data were divided into six groups. Each group included all U.S. traces with an ultrasonic wave within one of the six time intervals previously defined. The U.S. trace and the reference traces of each group were then averaged; this was done for each of the three sets of recorded data (See Tab. I.). A total of 18 averaging operations was carried out (Fig. 3 illustrates one of these).

In this way six ultrasonic waves were determined and were attributed the same letters of the alphabet as the corresponding intervals.

This analysis allowed us to compare the ultrasonic signals with the polygraphic traces generally used to analyze the electromechanical phases of the cardiac cycle. This also permitted us to determine precisely to which of these phases each of the six ultrasonic waves corresponded. 


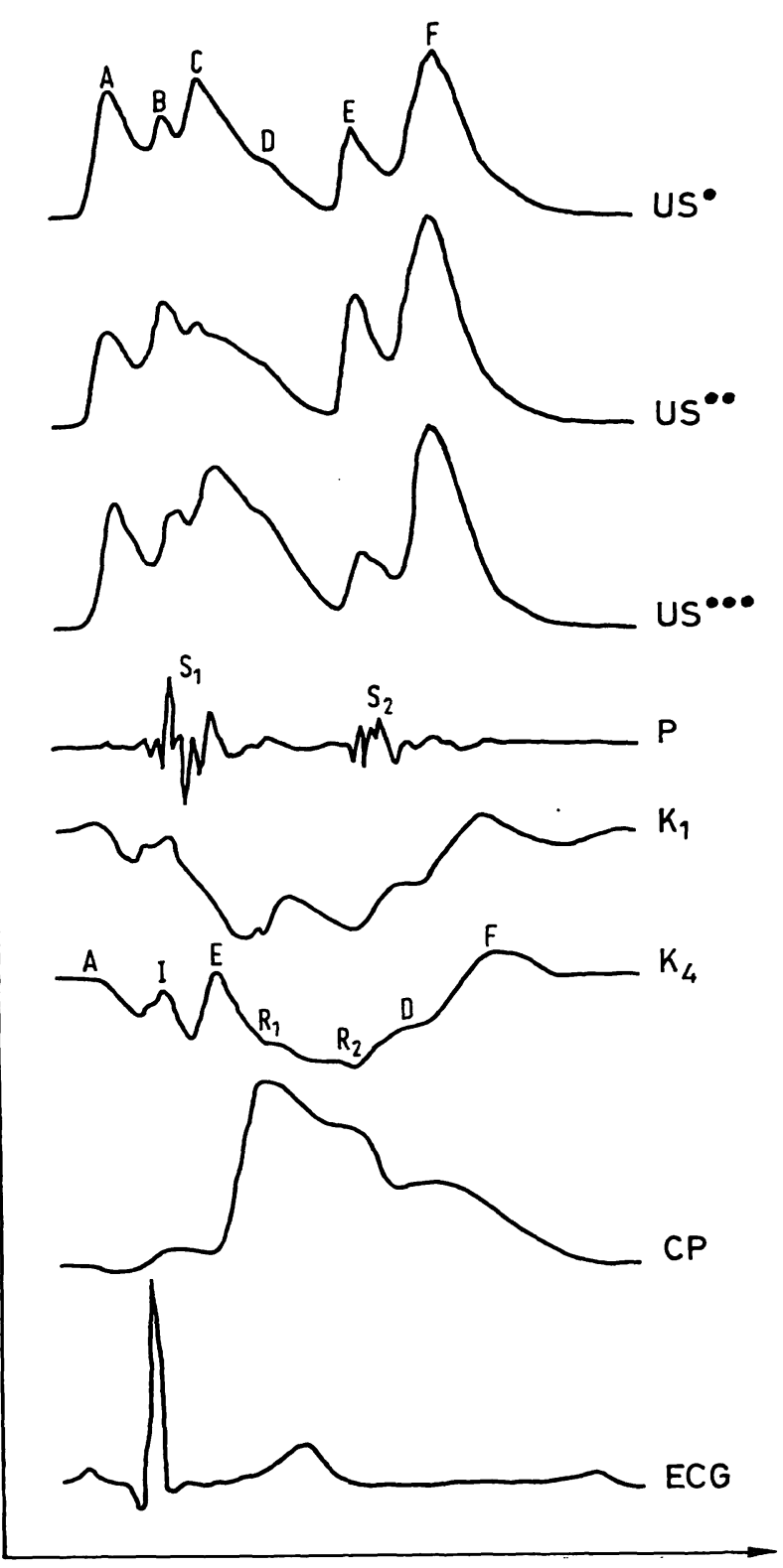

Fig. 4. Averaged recordings of all traces for the evaluation of the time of occurrence of U.S. waves. See legend Tab. I U. S. I $^{\bullet}$ series; U. S. ${ }^{\bullet \bullet}$ II $^{\bullet}$ series; U. S. ${ }^{\bullet \bullet}$ III $^{\bullet}$ series of recording.

\section{Results}

A compared examination of the ultrasound tracing with the other known indirect methods used in our study shows constant temporal relations (Fig. 4).

1) U.S. wave A occures in the same interval of the K. C. G. wave A (especially evident in $K_{1}$ ); the latter corresponding to atrial contraction and relaxation. The $\mathrm{P}$ wave on the E. C. G. precedes the A wave on the K. C. G. by approximately $40 \mathrm{msec}$.

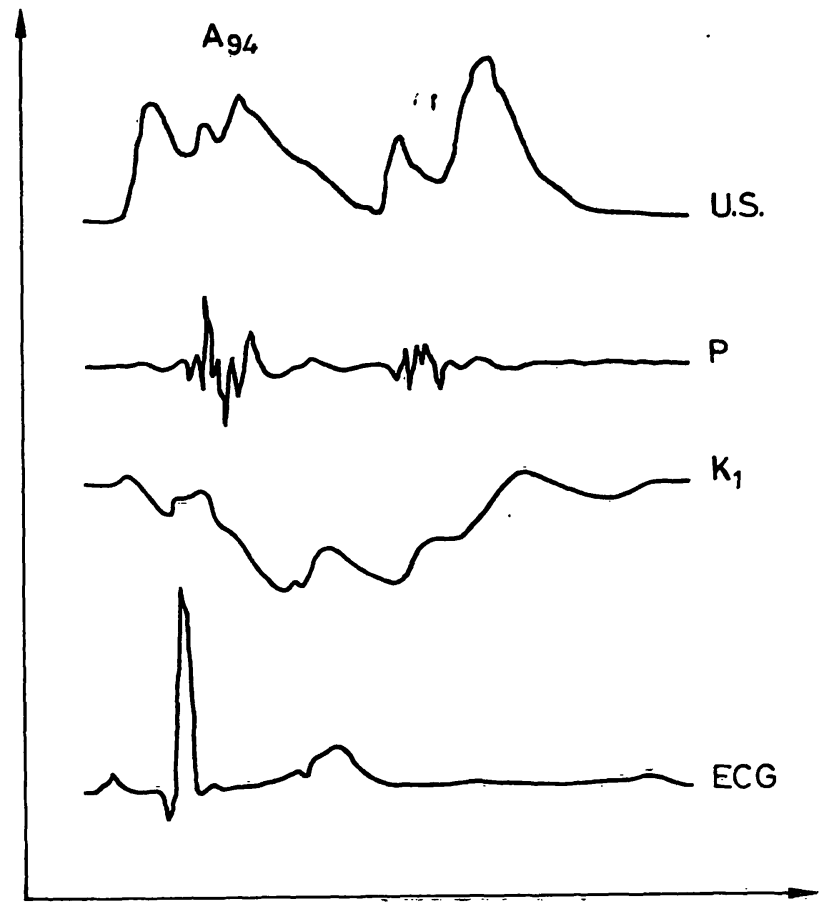

Fig. 3. Averaging performed on 94 cardiac evaluations of the second series traces in which $A$ wave was recorded. U. S., P., K $K_{1}$, E. C. G.: see legend Tab. I.

2) U.S. wave B begins simultaneously with the first heart sound and with the K. C. G. phenomena which refers to isovolumetric ventricular contraction (negative deflection in $\mathrm{K}_{4}$ called also $\mathrm{I}$, "isometrisch"; descending limb of A wave in $\mathrm{K}_{1}$ ).

3) U.S. wave $C$ onset is simultaneous to the $\mathrm{Ph}$. C. G. signal of semilunar valves opening and with the K. C. G. wave (both in $\mathrm{K}_{1}$ and $\mathrm{K}_{4}$ ) corresponding to the latency period between aortic valves opening and the ascending limb of the systolic carotid pulse.

4) D wave is the less defined of all the U.S. waves. Its onset corresponds to:

a) in $\mathrm{K}_{4}$ to the first "nadir" $\left(\mathrm{R}_{1}\right)$ of the negative deflection which marks the beginning of reduced ventricular ejection phase.

b) in $K_{1}$ to the mesosystolic lift of right ventricle caused by atrial filling (that is also the lowering of tricuspical valves rings); this is contemporary to the reduced right ejection time.

5) U.S. wave E begins together with the $\mathrm{II}^{0}$ heart sound and with the second "nadir" $\left(R_{2}\right)$ of the negative deflection in $\mathrm{K}_{4}$ which marks the end of the reduced left ventricular ejection. The $D$ wave in $K_{4}$ C. G. which immediately follows $R_{2}$ is attri- 
buted to the isovolumetric ventricular relaxation. 6 ) the onset of U.S. wave F is contemporary to the end of the $\mathrm{II}^{0}$ sound, to the dicrotic notch of the C.A.P. and and to the $K_{1}$ and $K_{4}$ waves representing ventricular filling.

\section{Discussion}

Present information concerning fetal cardiac activity is almost exclusively obtained from cardiac frequency trace readings. The development of ultrasonic techniques has not markedly improved the amount of possible information obtained. In fact, some of these techniques (M-mode display, filtration of DOPPLER signals) provide data of speculative interest, while others (combined use of pulsed Doppler and E. C. G., Q/M display) are technically too complex to be of clinical use.

Five DOPPLER signals can be obtained for each cardiac cycle in the fetus and in the adult $[3,9$, 12]. In previous fetal studies [12].we integrated and rectified these irregular biphasic signals into five regular waves. The ultrasonic technique we adopted is easy to perform and provides informative data.

The comparison with other parameters of widely accepted significance allowed us to determine accurately in the adult the phases of the cardiac cycle during which the ultrasonic waves appear. They are: A wave, atrial contraction; B wave, isovolumetric contraction; $C$ wave, opening of the semilunar valves and maximum ejection; $D$ wave, reduced ventricular ejection; $E$ wave, second sound of the P. C. G. and isovolumetric relaxation on the K. C. G. tracings; F wave, ventricular filling.

This analysis showed a peculiar wave between the third and fourth of the five waves previously defined by other authors and our group $[3,12]$. Waves $E$ and $F$ as described in our present work correspond to the fourth and fifth wave of previous reports.

\section{Summary}

It is well known that both in the fetal and adult heart five DOPPLER signals can be obtained for each cardiac cycle. In previous studies we integrated and rectified these irregular biphasic signals into five regular waves. Since these ultrasonic waves refer to corresponding dynamic pheno-
Further research is necessary to elucidate which moving structure (mycardium, valves, blood etc.) produces each ultrasonic wave. However the finding of a correlation between DOPPLER ultrasonic waves and differing phases of cardiac cycle is the first step towards our original aim: to set up a non-invasive technique to analyse systolic time intervals in the fetus.

This analysis cannot yet be performed as easily in the fetus as in the adult, but its development should yield a more comprehensive evaluation of fetal conditions than with the monitoring of fetal heart rate alone. Some interesting preliminary studies have been carried out by HoN's group on the neonate immediately after delivery. These studies indicate that alterations in $\mathrm{pH}$ influence the pre-ejection period (P.E. P.) and left ventricular ejection time (L.V.E.T.) as measured by traditional techniques (phonocardiogram, carotid pulse, E. C. G.) [14]. A similar correlation was sperimentally observed in monkey [6] and lamb fetuses [7].

In the human fetus these studies have to face with important limitations which are only partially overcome by means of indirect methods. Recently it was proposed to use the interval between the $R$ wave on the E.C.G. and the first sound of the $\mathrm{Ph}$. C. G. as a measure of the fetal P.E.P. during labour [4]. The first results that come from MoRGERSTERN's work seem to indicate that the P. E. P. is a sensitive indicator of fetal myocardial function [5].

Development of the DOPPLER technique may develop into the ideal tool to study fetal myocardial function with simplicity and directness while being non-invasive.

Our present work, like those of other authors [8] is moving in this direction; this original elaboration of DOPPLER signals provides a simple method to collect data on cardiac cycle time intervals.

mena in the cardiac cycle, they could be used in the measurement of fetal systolic time intervals.

The aim of the study was to determine which phase of the cardiac cycle corresponds to each wave. The ultrasonic signals were recorded simultaneously with other signals 
which are normally used to investigate cardiac activity. The research by necessity was carried out in the adult. Cardiac ultrasonic signals, phonocardiograms, carotid arterial pulse, kinetocardiograms and electrocardiograms were recorded in three healthy male subjects, 27, 29 and 35 years old. For practical reasons three series of differing combinations of these recordings were carried out in each subject (Tab. I). 712 of the 3000 cardiac revolutions recorded in the third subject were statistically analysed using a H.P. 2100 electronic calculator.

As a first result of this analysis a frequency polygon was constructed (Fig. 2) with the R-R interval on the abscissa, subdivided into 50 fractions and the number of ultrasonic signals which could be attributed to each fraction, on the ordinate. In this way it could be seen that the ultrasonic waves appeared within six well defined time intervals.

Subsequently the data were divided into six groups each of them including all traces with an ultrasonic wave within one of the time intervals previously defined. Each group was further subdivided into three series corresponding to the three sets of recordings.

The data from ultrasonic and reference traces were aver-

Keywords: Echocardiography, fetal heart.

\section{Zusammenfassung}

Vorläufige Untersuchungsergebnisse zur Verwendung von DOPPLER-Signalen für die Analyse der fetalen systolischen Herzaktion.

Es ist bekannt, daß jeder Erregungszyklus sowohl des fetalen wie auch des erwachsenen Herzens fünf DOPPLERSignale liefert.

In vorangegangenen Arbeiten ordneten wir diese unregelmäßigen biphasischen Signale durch Integration und Gleichrichtung fünf regelmäßigen Ultraschallkurven zu. Wenn sich diese Kurvenverläufe mit den hämodynamischen Phänomenen einer Herzaktion korrespondieren lassen, könnten sie zur Messung fetaler systolischer Zeitintervalle benutzt werden.

Das Ziel der vorliegenden Studie war die Zuordnung jeder Phase der Herzaktion zu einer der fünf Ultraschallkurveri. Hierzu wurden die Ultraschallsignale simultan mit den üblichen Parametern, die zur Charakterisierung der Herzaktionen benutzt werden, aufgezeichnet. Die Experimente mußten notwendigerweise am Herzen des Erwachsenen durchgeführt werden. Bei drei männlichen Versuchspersonen im Alter von 27, 29 und 35 Jahren registrierten wir kardiale Ultraschallsignale, Phonocardiogramme, Karotidenpulse, Kinetocardiogramme und Elektrocardiogramme. Aus praktischen Erwägungen wurden von jeder Versuchsperson 3 Serien mit jeweils wechselnden Kombinationen geschrieben (Tab. I). 712 von 3000 Herżaktionen, die bei dem dritten Patienten registriert worden waren, wurden statistisch mit einem elektronischen Rechner (H. P. 2100) analysiert.

Als erstes Ergebnis dieser Analyse konstruierten wir eine polygonale Häufigkeitsverteilung (Fig. 2). Auf der Abszisse wurde das R-R-Intervall, welches in 50 Abschnitte unterteilt war, abgetragen, auf der Ordinate die Anzahl der Ultraschallsignale, die jedem Abschnitt zugeordnet werden konnte. Jetzt wurde deutlich, daß die Ultraschall-

Schlüsselwörter: Elektrocardiographie, fetale Herzaktion. aged. In this way six ultrasonic waves were determined i. e. one more than had been observed in previous studies. They have been given the letters A, B, C, D, E and F. A total of eighteen averaging operations was carried out. Fig. 3 shows one of these.

This analysis has allowed the comparison of ultrasonic signals with the other parameters, as shown in Fig. 4, i. e. the temporal relationships between the ultrasonic and the other parameters. In this way we can probably ascertain the relationship between the ultrasonic waves and the electromechanical phases of the cardiac cycle. These temporal relations are: A wavè, atrial contraction; B wave, isovolumetric contraction; $\mathrm{C}$ wave, opening of semilunar valves and maximum ejection; $D$ wave, reduced ventricular ejection; $\mathrm{E}$ wave, isovolumetric relaxation; $\mathrm{F}$ wave, ventricular filling.

One of the most interesting subjects in the field of perinatal medicine is the analysis of systolic time intervals. However such measurements are technically difficult to perform. Ultrasonic DOPPLER signals may provide a non invasive analytical method by which they may be taken directly and simply.

kurven innerhalb von 6 gut gegeneinander abzugrenzenden Zeitintervallen auftauchten.

Der nächste Schritt war die Aufteilung aller Daten auf 6 Gruppen, wobei jede Gruppe alle registrierten Werte mit einer Ultraschallkurve eines der oben definierten Zeitintervalle zusammenschloß. Entsprechend den 3 Aufzeichnungsanordnungen wurde jede Gruppe noch einmäl in 3 Untergruppen geteilt.

Die Daten der Ultraschall- und Referenżaufzeichnungen wurden gemittelt, so dạ sich jetzt nicht mehr 5 wie in den vorangegangenen Untersuchungen, sondern 6 Ultraschallkurven voneinander abgrenzen ließen. Sie wurden mit den Buchstaben A, B, C, D, E und F gekennzeichnet. Zur Mittelung wurden insgesamt 18 Rechenoperationen durchgefuhrt, eine ist in Fig. 3 abgebildet.

Über diese Analyse war ein Vergleich von Ultraschallsignalen mit den anderen Parametern möglich, wie in Fig. 4 gezeigt wird. Insbesondere interessieren die zeitlichen Zusammenhänge zwischen Ultraschallsignalen und den übrigen Parametern und damit letztlich der Zusammenhang $\mathrm{zwischen}$ einer Ultraschallkurve und einem bestimmten Intervall der elektromechanischen Herzaktion, der jetzt ermittelt werden kann. Die zeitliche Zuordnung sieht wahrscheinlich so aus: A-Welle $\rightarrow$ Vorhofkontraktion; B-Welle $\rightarrow$ isovolumetrische Kontraktion; C-Welle $\rightarrow$ Öffnung der Semilunarklappen und maximale Austreibung; D-Welle $\rightarrow$ verminderter Auswurf; E-Welle $\rightarrow$ isovolumetrische Entspannung; F-Welle $\rightarrow$ Ventrikelfüllung.

Die Analyse der systolischen Zeitintervalle ist eine der interessantesten Fragestellungen auf dem Gebiet der perinatalen Medizin. Die hierzu notwendigen Messungen sind jedoch technisch schwierig durchzufuhren. Mit der Auswertung der Ultraschall-DOPPLER-Signale steht vielleicht eine nicht-invasive Methode zur Verfügung, durch die Informationen über die fetale systolische Herzaktion direkt und einfach gewonnen werden können. 


\section{Résumé}

Etudes préliminaires sur la possibilité d'utilisation des signaux DOPPLER dans l'analyse de l'intervalle de temps systolique du coeur foetal.

Il est bien connu qu'il est possible d'obtenir cinq signaux DOPPLER pour chaque révolution cardiaque aussi bien pour le coeur foetal que pour celui de l'adulte.

Des études antérieures nous ont permis d'intégrer et de rectifier ces signaux irréguliers biphasiques en cinq ondes régulièrers. Puisque ces ondes sonographiques semblent correspondre à des Phénomènes dynamiques, elles peuvent être utilisées pour la mesure des intervalles de temps systoliques foetaux.

L'objet de cette étude était de déterminer la phase du cycle cardiaque qui correspond à chaque onde. Les signaux sonographiques ont été enregistrés simultanément aved d'autres signaux normalement utilisés dans l'étude de l'activité cardiaque. Forcement d'étude a été réalisée chez l'adulte. Chez trois sujets masculins sains de 27, 29 et 35 ans nous avons enregistré les signaux cardiaques sonographiques, les phonocardiogrammes, le pouls artériel carotidien, le cinétocardiogramme ainsi que l'électrocardiogramm. Pour des raisons pratiques nous avons déduit trois séries de différentes combinaisons des ces enregistrements pour chaque sujet (Tab. I). 712 des 3000 révolutions cardiaques enregistrées chez le troisième sujet ont été analysées statistiquement au moyen d'un ordinateur électronique H. P. 2100.

Le premier résultat de cette étude était la construction d'un polygone de fréquence (fig. 2) avec. en abscisse, l'intervalle $R-R$ subdivisé en 50 fractions et, en ordonnée, le nombre des signaux sonographiques qui pouvaient être rattachés à chaque fraction. Il apparaissait ainsi que les ondes sonographiques se distribuaient en six intervalles de temps bien définis.

Par la suite les données ont été partagées en six groupes, chaqun incluant l'ensemble des tracés à onde sonographique située à l'intérieur de l'intervalle de temps antérieurement défini. Chaque groupe était ensuite subdivisé en trois séries corréspondant aux trois collections d'enregistrements.

Nous avons obtenu des moyennes des données sonographiques et de celles de référence. Ainsi ont été déterminées six ondes sonographiques, c'est-à-dire une de plus par rapport à nos observations antérieures. Nous les avons appelées des lettres A, B, C, D, E et F. Nous avons réalisé au total dix-huit opérations de calcul de moyenne. La figure 3 en montre une.

Cette étude a permis la comparaison des signaux sonographiques avec les autres paramètres, comme le montre la fig. 4, c'est-à-dire la relation dans le temps entre les paramètres sonographiques et les autres. Ainsi pourronsnous peut-être constater une relation entre les ondes sonographiques et les phases électroméchaniques du cycle cardiaque. Ces relations dans le temps étaien les suivantes: onde $A$, contraction auriculaire; onde $B$, contraction isovolumétrique; onde $C$, ouverture des valvules interauriculo-ventriculaires et éjection maximale; onde $D$, éjection ventriculaire réduite; onde $\mathrm{E}$, relaxation isovolumétrique; onde $F$, remplissage ven triculaire.

L'analyse du temps systolique est l'un des plus intéressants sujets dans le domaine de la médecine périnatale. De telles mesures sont cependant difficiles à réaliser. Les signaux sonographiques DOPPLER pourraient constituer une méthode d'analyse non invasive permettant de les réaliser simplement et directement.

Mots-clès: Coeur foetal, électrocardiographie.

Acknowledgement: This work was supported by grants from Consiglio Nazionale delle Ricerche (Project $\mathrm{n}^{0}$ 73.01386.43.115.6808).

The authors are most grateful to Miss SUSAN ARNOLD M. D. for her helpful suggestions in translating the manuscript.

\section{Bibliography}

[1] BISHOP, E. H.: Obstetric uses of the ultrasonic motion sensor. Am. J. Obstet Gynec. 96 (1966) 863

[2] EDDLEMAN, E. E. Jr., K. WILLIS, T. J. REEVES, T. R. HARRISON: The kinetocardiogram. I. Method of recording precordial movements. Circulation 8 (1953) 269

[3] MAEDA, K.: External monitoring of the fetus during pregnancy and labor. Yonago Acta Medica 15 (1971) 129

[4] MORGENSTERN, J., H. CERNY, H. SCHMIDT, J. SCHULZ, R. STURM, K. WERNICKE, F. WIESNER: Systolic and diastolic time intervals of fetal cardiac cycle. Material and methods. Abstracts of the VIII World Congress of Gynaecol. and Obstet. Excerpta Medica, Amsterdam 1976
[5] MORgENSTERN, J., H. CZERNY, H. SCHMIDT, J. SCHULZ, K. WERNICKE: Systolic time intervals of the fetal cardiac cycle. J. Perinat. Med. 6 (1978) 173

[6] MURAtA, Y., C. B. MARTin, T. IKenOUE, R. H. PETRIE: Cardiac systolic time intervals in fetal monkeys: Pre-ejection period. Am. J. Obstet. Gynec. 132 (1978) 285

[7] MURATA, Y., K. MIYAKE, E. J. QUILligaN: Preejection period of cardiac cycles of fetal lamb. Am. J. Obstet. Gynec. 133 (1979) 511

[8] MURATA, Y., C. B. MARTIN, T. IKENOUE, P. S. LU: Antepartum evaluation of the pre-ejection period of fetal cardiac cycle. Am. J. Obstet. Gynec. 132 (1978) 278 
[9] NIMURA, Y., H. MATSUO, S. MOCHIZUKU, K. AOKI, O. WADA, H. ABE: Analysis of a cardiac cycle of the left side of the heart in cases of left ventricular overloading or damage with the ultrasonic Doppler method. Am. Heart J. 75 (1968) 49

[10] ROVERSI, G. D., V. CANUSSIO, A. FERRARI, F. GORINI, G. TRONCONI, J. L. BEAUSSART: Elaborazione elettronica dei segnali ultrasonici del cuore fetale, del funicolo e della placenta: nuovo metodo di conteggio automatico della frequenza cardiaca fetale. Ann. Ost. Ginec. 4 (1968) 253

[11] Roversi, G. D., V. CANUSSIO, G. G. CABIBBE, J. L. BEAUSSART: L'impiego degli ultrasuoni (effetto DOPPLER) nello studio dell'attività cardiaca fetale: possibilità e limiti. Ann. Ost. Ginec. 4 (1970) 1

[12] ROVERSI, G. D., V. CANUSSIO, F. GORINI, J. L. BEAUSSART: Utilization of ultrasound DOPPLER effect for studying foetal cardiac activity. Ultrasonics 10 (1972) 114

[13] PERSONAL DATA (not published)

[14] ZANINI, D.: La frequenza cardiaca ed altri parametri cardiaci nel feto e nel neonato prematuro. Atti del IV Corso Nazionale di Aggiornamento in Medicina Perinatale (in press)

Received December 17, 1979. Revised from February 19, 1980 - May 7, 1980. Accepted May 12, 1980.

Prof. Gian Domenico Roversi

Via E. Besana, 6

I-20122 Milano 